\title{
Identifying Muscle Growth-Related Genes of Mandarin Fish (Siniperca chuatsi) by Transcriptome, and Exploring the Expression in Different Sizes and Compensatory Growth
}

\section{Xuange Liu}

Sun Yat-Sen University

Shuang Zeng

Sun Yat-Sen University

Shuang Liu

Sun Yat-Sen University

Gongpei Wang

Sun Yat-Sen University

Han Lai

Sun Yat-Sen University

Xiaopin Zhao

Sun Yat-Sen University

Sheng Bi

Sun Yat-Sen University

Dingli Guo

Sun Yat-Sen University

Xiaoli Chen

Sun Yat-Sen University

Huadong Yi

Sun Yat-Sen University

Yuqing Su

Sun Yat-Sen University

Guifeng Li ( $\square$ liguif@mail.sysu.edu.cn )

Sun Yat-Sen University https://orcid.org/0000-0002-6724-5462

Research article

Keywords: mandarin fish, RNA-seq, compensatory growth, muscle growth-related genes

Posted Date: March 3rd, 2020 
DOI: https://doi.org/10.21203/rs.3.rs-15752/v1

License: (c) (1) This work is licensed under a Creative Commons Attribution 4.0 International License. Read Full License 


\section{Abstract}

\section{Background}

How organisms display many different biochemical, physiological processes through genes expression and regulatory mechanisms affecting muscle growth is a central issue in growth and development. In Siniperca chuatsi, the growth-related genes and underlying relevant mechanisms are poorly understood, especially for difference of body sizes and compensatory growth performance.

\section{Results}

The muscle from different sizes of individuals was subjected to transcriptome analysis by RNAsequencing. Results showed that 8,942 different expression genes (DEGs) were identified after calculating the RPKM. The DEGs involved in GH-IGF pathways, protein synthesis, ribosome synthesis and energy metabolisms, which were expressed at higher level in small individuals $(\mathrm{S})$, whereas in the large fish (L) little expression was found. In repletion feeding and compensatory growth experiments, 8 more significant DEGs were used for further research (GHR2, IGFR1, 4ebp, Mhc, Mlc, Myf6, MyoD, troponin), and this research revealed different temporal and spatial expression patterns of these genes. When food was plentiful, 8 genes participated in and promoted the growth and muscle synthesis, respectively. Starvation can be shown to inhibit the expression of Mhc, Mlc and troponin, and high expression of GHR2, IGFR1 and 4ebp inhibited growth. MyoD can sense and regulate the hunger and work with Mhc and Mlc to accelerate the compensatory growth of S.chuatsi.

\section{Conclusions}

This study is helpful to understand the regulation mechanisms of muscle growth-related genes. The elected genes will contribute to the selective breeding in future as candidate genes.

\section{Background}

Muscle growth is regulated by the genes expression nets of muscle cell proliferation and protein metabolism [1]. In vertebrates, several growth-related genes have been identified, including Myogenic Regulatory Factors (MRFs), insulin-like growth factor (IGF), IGF receptors (IGFR), growth hormone (GH), $\mathrm{GH}$ receptors (GHR) [2,3]. Interestingly, for mammals, muscle growth occurs mainly by hypertrophy, with little proliferation. Unlike mammals, fish muscle growth is achieved by hyperplasia and hypertrophy [4]. Furthermore, in large and fast-growing fish, both hyperplasia and hypertrophy contribute to muscle growth and continue into a large body size, whereas small and slow-growing fish largely rely on hypertrophy and the rate of muscle fiber recruitment is rather low [5-7]. Thus, the same genes may have different expression and regulatory mechanisms in different fish. Studies on genes expression of different sizes and compensatory growth prove fruitful for comprehending growth regulatory mechanisms of fish [8-11]. 
Body size is an obvious and vital characteristic of fish, which is controlled by cell number and cell size [12], and this process is tightly modulated by growth-related genes and nutrition. An adequate re-feeding following a period of starvation or unfavorable environmental conditions can occur accelerated growth, which is called compensatory growth and has been widely studied in vertebrates $[10,11,13,14]$. Especially, it has been reported that fish has the capable of compensatory growth [14]. In the meantime, transcriptome analysis can identify growth-related genes and expand knowledge in body size and compensatory growth, promoting the enhanced rate of food utilization and cut costs in aquaculture industry.

Transcriptome and RNA-sequencing (RNA-seq) have been applied to a substantial amount of fish biology studies, including zebrafish [15], channel catfish [16], European sea bass [17], and rainbow trout [18]. Many biological processes, including development, immune, stress response, and adaptive evolution can be mapped, annotated and understood by RNA-seq.

S.chuatsi is an important commercial fresh water fish in China. At present, the research on S.chuatsi mainly focuses on aquaculture, disease and immunity, nevertheless the growth-related genes and mechanisms are not well understood [19-21]. To this end, different sizes muscle of S.chuatsi was subjected to transcriptome analysis by RNA-seq and explores the mechanisms of growth-related genes by compensatory growth in this study. The results would be helpful to find significantly molecule markers for selective breeding.

\section{Results}

\section{Sequencing and annotation}

The different weight of S.chuatsi was shown in Table 1. The brief information of Illumina deep sequencing was shown in Table 2. A total of 91,264,026 high quality clean reads (48963598 belongs $L$, 46617484 belongs $S$ ) were obtained (Table 2). After screening, 39005 unigenes were annotated into four databases, including $\mathrm{Nr}(38833,52.9 \%)$, Swissport (337479, 46.0\%), COG (10926, 14.8\%) and KEGG $(19791,26.9 \%)$ (Fig. 1). So, we annotated the results by $\mathrm{Nr}$ database which defined the maximum number of unigenes. 
Table 1

Growth traits of overweight and underweight Siniperca chuatsi

\begin{tabular}{|llll|}
\hline individual & Weight $(\mathbf{g})$ & Length $(\mathrm{mm})$ & Height $(\mathrm{mm})$ \\
\hline L-1 & 62.2 & 138 & 46 \\
\hline L-2 & 80.1 & 147 & 52 \\
L-3 & 55.2 & 132 & 43 \\
\hline L-4 & 54.3 & 131 & 45 \\
\hline L-5 & 59.3 & 135 & 44 \\
\hline S-1 & 12.6 & 79 & 24 \\
\hline S-2 & 7.8 & 71 & 23 \\
\hline S-3 & 16 & 85 & 26 \\
\hline S-4 & 12.9 & 82 & 24 \\
\hline S-5 & 12.8 & 79 & 26 \\
\hline Note: L means Large individual, S means Small individual. \\
\hline
\end{tabular}

Table 2

The brief information of deep sequencing and assembly for overweight and underweight in Siniperca chuatsi

\begin{tabular}{|ll|}
\hline Category & Number \\
\hline Number of reads & $95,581,082$ \\
\hline Clean Reads & $91,264,026(95.48 \%)$ \\
\hline Total Nucleotides(nt) & $9,126,402,600$ \\
\hline Q20 ratio (\%) & $98.57 \%$ \\
\hline N ratio (\%) & $0.00 \%$ \\
\hline GC ratio (\%) & $51.31 \%$ \\
\hline Number of contigs & 80,314 \\
\hline Average length of unigenes & 621 \\
\hline Number of unigenes & 73,353 \\
\hline Average length of unigenes (bp) & 703 \\
\hline
\end{tabular}




\section{Analysis of RNA-seq data and confirmation}

By GO terms enrichment analysis, the biological process, cellular component and molecular function have 1530, 1737 and 1883 genes respectively (Fig. 2), which illustrated the dominant groups was cellular process in biological process, cell and cell part in cellular component and binding in molecular function (Fig. 2). 8,942 DEGs were identified after calculating the RPKM. Among them, 1084 unigenes were upregulated in L, while 7858 unigenes were up-regulated expressed in S (Fig. 3). The results showed that more genes were up-regulated in S compared to L (Fig. 3), including GH-IGF pathways receptors and

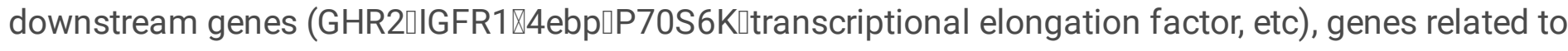
muscle synthesis and contraction ( $\mathrm{MHC} \square \mathrm{Mlc} \square$ troponin, etc) and energy metabolism gene (Glucose- 6 phosphate dehydrogenase etc) (Table 3). Thus, 8 genes were selected for further research by real-time

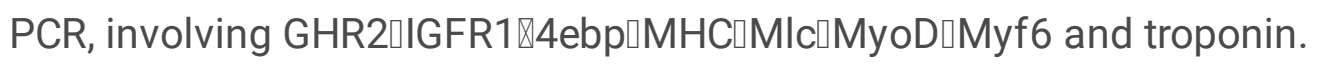


Table 3

The different expression genes between underweight and overweight in Siniperca chuatsi

\begin{tabular}{|c|c|c|c|c|c|c|}
\hline Gene ID & Annotation & $\begin{array}{l}\text { Underweight } \\
\text { RPKM }\end{array}$ & $\begin{array}{l}\text { Overweight } \\
\text { RPKM }\end{array}$ & $\begin{array}{l}\text { log2 } \\
\text { Ratio }\end{array}$ & $\begin{array}{l}\mathrm{P}- \\
\text { value }\end{array}$ & FDR \\
\hline \multicolumn{7}{|l|}{ IGF system } \\
\hline Unigene 0026866 & $\begin{array}{l}\text { type } 1 \text { insulin-like } \\
\text { growth factor } \\
\text { receptor }\end{array}$ & 1.517 & 0.001 & -10.567 & $\begin{array}{l}6.09 \mathrm{E}- \\
07\end{array}$ & $\begin{array}{l}5.42 \mathrm{E}- \\
06\end{array}$ \\
\hline Unigene 0012575 & $\begin{array}{l}\text { Insulin-like growth } \\
\text { factor } 2 \text { receptor }\end{array}$ & 3.936 & 0.891 & -2.143 & $\begin{array}{l}1.54 \mathrm{E}- \\
16\end{array}$ & $\begin{array}{l}3.34 \mathrm{E}- \\
15\end{array}$ \\
\hline Unigene 0054506 & $\begin{array}{l}\text { insulin receptor } \\
\text { substrate 2-like }\end{array}$ & 20.124 & 5.191 & -1.955 & $\begin{array}{l}3.20 \mathrm{E}- \\
276\end{array}$ & $\begin{array}{l}5.24 \mathrm{E}- \\
274\end{array}$ \\
\hline Unigene 0029023 & $\begin{array}{l}\text { insulin-like growth } \\
\text { factor binding } \\
\text { protein-1 }\end{array}$ & 7.535 & 3.251 & -1.213 & $\begin{array}{l}2.69 \mathrm{E}- \\
30\end{array}$ & $\begin{array}{l}9.85 \mathrm{E}- \\
29\end{array}$ \\
\hline Unigene 0010948 & $\begin{array}{l}\text { ribosomal protein } \\
\text { S6 kinase beta- } 1\end{array}$ & 0.959 & 0.048 & -4.309 & $\begin{array}{l}1.39 \mathrm{E}- \\
05\end{array}$ & $\begin{array}{l}9.96 \mathrm{E}- \\
05\end{array}$ \\
\hline Unigene 0047933 & $\begin{array}{l}\text { ribosomal protein } \\
\text { S6 kinase alpha-1 } \\
\text { isoform X1 }\end{array}$ & 4.687 & 1.575 & -1.573 & $\begin{array}{l}2.11 \mathrm{E}- \\
07\end{array}$ & $\begin{array}{l}2.01 \mathrm{E}- \\
06\end{array}$ \\
\hline Unigene 0038236 & $\begin{array}{l}\text { Ribosomal protein } \\
\text { S6 kinase alpha- } 6 \text {, }\end{array}$ & 0.521 & 0.125 & -2.061 & $\begin{array}{l}1.04 \mathrm{E}- \\
07\end{array}$ & $\begin{array}{l}1.03 \mathrm{E}- \\
06\end{array}$ \\
\hline Unigene0060291 & $\begin{array}{l}\text { eukaryotic } \\
\text { translation initiation } \\
\text { factor 4E-binding } \\
\text { protein }\end{array}$ & 45.133 & 5.536 & -3.027 & $\begin{array}{l}3.95 \mathrm{E}- \\
216\end{array}$ & $\begin{array}{l}5.91 \mathrm{E}- \\
214\end{array}$ \\
\hline Unigene 0023276 & $\begin{array}{l}\text { eukaryotic } \\
\text { translation initiation } \\
\text { factor } 2 \text {-alpha } \\
\text { kinase } 1\end{array}$ & 0.797 & 0.001 & -9.638 & $\begin{array}{l}4.43 \mathrm{E}- \\
05\end{array}$ & $\begin{array}{l}2.84 \mathrm{E}- \\
04\end{array}$ \\
\hline Unigene 0056547 & $\begin{array}{l}\text { elongation factor Tu } \\
\text { GTP-binding } \\
\text { domain-containing } \\
\text { protein } 1 \text { isoform } 2\end{array}$ & 1.813 & 0.404 & -2.165 & $\begin{array}{l}1.61 \mathrm{E}- \\
06\end{array}$ & $\begin{array}{l}1.35 \mathrm{E}- \\
05\end{array}$ \\
\hline Unigene0059231 & $\begin{array}{l}\text { elongation factor Tu } \\
\text { GTP-binding } \\
\text { domain-containing } \\
\text { protein } 1 \text { isoform X1 }\end{array}$ & 1.337 & 0.427 & -1.646 & $\begin{array}{l}4.45 \mathrm{E}- \\
05\end{array}$ & $\begin{array}{l}2.85 \mathrm{E}- \\
04\end{array}$ \\
\hline Unigene 0052980 & $\begin{array}{l}\text { GTP-binding protein } \\
\text { Rheb }\end{array}$ & 17.230 & 8.132 & -1.083 & $\begin{array}{l}2.72 \mathrm{E}- \\
41\end{array}$ & $\begin{array}{l}1.31 \mathrm{E}- \\
39\end{array}$ \\
\hline Unigene 0037630 & $\begin{array}{l}\text { Ras-related protein } \\
\text { Rap-1A }\end{array}$ & 0.712 & 0.246 & -1.535 & $\begin{array}{l}4.21 \mathrm{E}- \\
05\end{array}$ & $\begin{array}{l}2.74 \mathrm{E}- \\
04\end{array}$ \\
\hline
\end{tabular}




\begin{tabular}{|c|c|c|c|c|c|c|}
\hline Gene ID & Annotation & $\begin{array}{l}\text { Underweight } \\
\text { RPKM }\end{array}$ & $\begin{array}{l}\text { Overweight } \\
\text { RPKM }\end{array}$ & $\begin{array}{l}\log 2 \\
\text { Ratio }\end{array}$ & $\begin{array}{l}\text { P- } \\
\text { value }\end{array}$ & FDR \\
\hline Unigene0059752 & $\begin{array}{l}\text { MAPK kinase- } \\
\text { interacting } \\
\text { serine/threonine- } \\
\text { protein kinase } 1 \\
\text { isoform X1 }\end{array}$ & 6.727 & 2.459 & -1.452 & $\begin{array}{l}8.03 \mathrm{E}- \\
29\end{array}$ & $\begin{array}{l}2.83 \mathrm{E}- \\
27\end{array}$ \\
\hline Unigene0036862 & $\begin{array}{l}\text { TGF-beta-activated } \\
\text { kinase } 1 \text { and } \\
\text { MAP3K7-binding } \\
\text { protein } 1\end{array}$ & 5.344 & 1.770 & -1.594 & $\begin{array}{l}2.14 \mathrm{E}- \\
27\end{array}$ & $\begin{array}{l}7.19 \mathrm{E}- \\
26\end{array}$ \\
\hline Unigene0071651 & $\begin{array}{l}\text { mitogen-activated } \\
\text { protein kinase } \\
\text { kinase kinase } 5\end{array}$ & 3.057 & 1.302 & -1.231 & $\begin{array}{l}1.48 \mathrm{E}- \\
13\end{array}$ & $\begin{array}{l}2.63 \mathrm{E}- \\
12\end{array}$ \\
\hline Unigene0074102 & $\begin{array}{l}\text { growth hormone } \\
\text { receptor isoform } 1\end{array}$ & 23.867 & 4.137 & -2.528 & $\begin{array}{l}5.05 \mathrm{E}- \\
164\end{array}$ & $\begin{array}{l}6.66 \mathrm{E}- \\
162\end{array}$ \\
\hline \multicolumn{7}{|c|}{ Protein synthesis(myosin) } \\
\hline Unigene0068992 & myosin light chain 1 & 3.163 & 0.253 & -3.646 & $\begin{array}{l}3.44 \mathrm{E}- \\
06\end{array}$ & $\begin{array}{l}2.74 \mathrm{E}- \\
05\end{array}$ \\
\hline Unigene0068993 & myosin light chain 1 & 6.423 & 0.058 & -6.789 & $\begin{array}{l}6.95 \mathrm{E}- \\
32\end{array}$ & $\begin{array}{l}2.66 \mathrm{E}- \\
30\end{array}$ \\
\hline Unigene0008763 & $\begin{array}{l}\text { Slow myosin heavy } \\
\text { chain } 1\end{array}$ & 1.017 & 0.334 & -1.609 & $\begin{array}{l}1.61 \mathrm{E}- \\
07\end{array}$ & $\begin{array}{l}1.55 \mathrm{E}- \\
06\end{array}$ \\
\hline Unigene0032403 & $\begin{array}{l}\text { Tropomyosin alpha- } \\
1 \text { chain }\end{array}$ & 2.572 & 0.183 & -3.816 & $\begin{array}{l}4.96 \mathrm{E}- \\
07\end{array}$ & $\begin{array}{l}4.48 \mathrm{E}- \\
06\end{array}$ \\
\hline Unigene0021259 & $\begin{array}{l}\text { myosin heavy chain, } \\
\text { fast skeletal muscle- } \\
\text { like }\end{array}$ & 4.050 & 0.578 & -2.808 & $\begin{array}{l}5.39 \mathrm{E}- \\
09\end{array}$ & $\begin{array}{l}6.18 \mathrm{E}- \\
08\end{array}$ \\
\hline Unigene0002916 & actin & 5.893 & 0.741 & -2.991 & $\begin{array}{l}5.70 \mathrm{E}- \\
12\end{array}$ & $\begin{array}{l}8.74 \mathrm{E}- \\
11\end{array}$ \\
\hline Unigene0058346 & $\begin{array}{l}\text { Activin receptor } \\
\text { type-1B }\end{array}$ & 2.769 & 0.992 & -1.481 & $\begin{array}{l}6.59 \mathrm{E}- \\
08\end{array}$ & $\begin{array}{l}6.70 \mathrm{E}- \\
07\end{array}$ \\
\hline Unigene0023112 & myogenic factor 6 & 8.409 & 3.309 & 1.3464 & $\begin{array}{l}1.94 \mathrm{E}- \\
21\end{array}$ & $\begin{array}{l}5.25 \mathrm{E}- \\
20\end{array}$ \\
\hline \multicolumn{7}{|c|}{ Ribosome systhesis } \\
\hline Unigene0021505 & $\begin{array}{l}\text { WD repeat- } \\
\text { containing protein } 3\end{array}$ & 3.780 & 0.617 & 2.616 & $\begin{array}{l}1.37 \mathrm{E}- \\
15\end{array}$ & $\begin{array}{l}2.81 \mathrm{E}- \\
14\end{array}$ \\
\hline Unigene0028009 & $\begin{array}{l}\text { ribonuclease } P \\
\text { protein subunit p40 }\end{array}$ & 5.950 & 1.123 & -2.405 & $\begin{array}{l}8.85 \mathrm{E}- \\
64\end{array}$ & $\begin{array}{l}6.18 \mathrm{E}- \\
62\end{array}$ \\
\hline
\end{tabular}




\begin{tabular}{|c|c|c|c|c|c|c|}
\hline Gene ID & Annotation & $\begin{array}{l}\text { Underweight } \\
\text { RPKM }\end{array}$ & $\begin{array}{l}\text { Overweight } \\
\text { RPKM }\end{array}$ & $\begin{array}{l}\text { log2 } \\
\text { Ratio }\end{array}$ & $\begin{array}{l}P \text { - } \\
\text { value }\end{array}$ & FDR \\
\hline Unigene0028767 & $\begin{array}{l}\text { U3 small nucleolar } \\
\text { RNA-associated } \\
\text { protein } 18 \text { homolog }\end{array}$ & 4.367 & 0.976 & -2.162 & $\begin{array}{l}5.92 \mathrm{E}- \\
37\end{array}$ & $\begin{array}{l}2.57 \mathrm{E}- \\
35\end{array}$ \\
\hline Unigene0038257 & $\begin{array}{l}\text { ribosomal RNA } \\
\text { small subunit } \\
\text { methyltransferase } \\
\text { NEP1 }\end{array}$ & 5.854 & 1.982 & -1.562 & $\begin{array}{l}5.71 \mathrm{E}- \\
17\end{array}$ & $\begin{array}{l}1.26 \mathrm{E}- \\
15\end{array}$ \\
\hline Unigene0025207 & $\begin{array}{l}\text { ribosome } \\
\text { maturation protein } \\
\text { SBDS }\end{array}$ & 13.361 & 4.897 & -1.448 & $\begin{array}{l}1.05 \mathrm{E}- \\
59\end{array}$ & $\begin{array}{l}7.00 \mathrm{E}- \\
58\end{array}$ \\
\hline Unigene0036337 & $\begin{array}{l}\text { U3 small nucleolar } \\
\text { ribonucleoprotein } \\
\text { protein IMP3 }\end{array}$ & 9.784 & 4.186 & -1.225 & $\begin{array}{l}2.97 \mathrm{E}- \\
26\end{array}$ & $\begin{array}{l}9.59 \mathrm{E}- \\
25\end{array}$ \\
\hline Unigene0033017 & $\begin{array}{l}\text { SET and MYND } \\
\text { domain-containing } \\
\text { protein } 1 \text { isoform } 2\end{array}$ & 0.707 & 0.208 & -1.762 & $\begin{array}{l}4.03 \mathrm{E}- \\
06\end{array}$ & $\begin{array}{l}3.17 \mathrm{E}- \\
05\end{array}$ \\
\hline Unigene 0073572 & $\begin{array}{l}\text { SET and MYND } \\
\text { domain-containing } \\
\text { protein } 5\end{array}$ & 6.901 & 3.190 & -1.113 & $\begin{array}{l}8.29 \mathrm{E}- \\
21\end{array}$ & $\begin{array}{l}2.19 \mathrm{E}- \\
19\end{array}$ \\
\hline \multicolumn{7}{|c|}{ Energy metabolism } \\
\hline Unigene0047705 & hexokinase & 3.809 & 1.657 & 1.201 & $\begin{array}{l}6.71 \mathrm{E}- \\
15\end{array}$ & $\begin{array}{l}1.32 \mathrm{E}- \\
13\end{array}$ \\
\hline Unigene0047702 & hexokinase-2 & 11.175 & 1.254 & -3.156 & $\begin{array}{l}5.87 \mathrm{E}- \\
39\end{array}$ & $\begin{array}{l}2.67 \mathrm{E}- \\
37\end{array}$ \\
\hline Unigene0012253 & $\begin{array}{l}\text { Pyruvate } \\
\text { dehydrogenase } \\
\text { kinase isozyme 1, } \\
\text { mitochondrial } \\
\text { isoform } 4\end{array}$ & 2.384 & 1.031 & -1.209 & $\begin{array}{l}1.37 \mathrm{E}- \\
10\end{array}$ & $\begin{array}{l}1.83 \mathrm{E}- \\
09\end{array}$ \\
\hline Unigene0038645 & $\begin{array}{l}\text { acyl-CoA synthetase } \\
\text { long-chain family } \\
\text { member } 4\end{array}$ & 1.721 & 0.458 & -1.909 & $\begin{array}{l}5.43 \mathrm{E}- \\
05\end{array}$ & $\begin{array}{l}3.43 \mathrm{E}- \\
04\end{array}$ \\
\hline Unigene0066639 & $\begin{array}{l}\text { acyl-CoA } \\
\text { dehydrogenase } \\
\text { family member } 11\end{array}$ & 1.034 & 0.384 & -1.428 & $\begin{array}{l}1.22 \mathrm{E}- \\
04\end{array}$ & $\begin{array}{l}7.11 \mathrm{E}- \\
04\end{array}$ \\
\hline Unigene0048024 & $\begin{array}{l}\text { short-chain specific } \\
\text { acyl-CoA } \\
\text { dehydrogenase, } \\
\text { mitochondrial } \\
\text { precursor }\end{array}$ & 7.953 & 3.562 & -1.159 & $\begin{array}{l}2.99 \mathrm{E}- \\
56\end{array}$ & $\begin{array}{l}1.89 \mathrm{E}- \\
54\end{array}$ \\
\hline
\end{tabular}




\begin{tabular}{|c|c|c|c|c|c|c|}
\hline Gene ID & Annotation & $\begin{array}{l}\text { Underweight } \\
\text { RPKM }\end{array}$ & $\begin{array}{l}\text { Overweight } \\
\text { RPKM }\end{array}$ & $\begin{array}{l}\log 2 \\
\text { Ratio }\end{array}$ & $\begin{array}{l}P \text { - } \\
\text { value }\end{array}$ & FDR \\
\hline Unigene0053754 & $\begin{array}{l}\text { heat shock protein } \\
70\end{array}$ & 3.978 & 0.168 & -4.564 & $\begin{array}{l}6.41 \mathrm{E}- \\
18\end{array}$ & $\begin{array}{l}1.48 \mathrm{E}- \\
16\end{array}$ \\
\hline Unigene0022967 & $\begin{array}{l}\text { heat shock protein } \\
\text { hsp90 beta }\end{array}$ & 8.095 & 1.880 & -2.106 & $\begin{array}{l}6.28 \mathrm{E}- \\
95\end{array}$ & $\begin{array}{l}5.87 \mathrm{E}- \\
93\end{array}$ \\
\hline Unigene0029204 & $\begin{array}{l}\text { heat shock protein } \\
\text { HSP 90-alpha }\end{array}$ & 15.907 & 7.477 & -1.089 & $\begin{array}{l}6.52 \mathrm{E}- \\
13\end{array}$ & $\begin{array}{l}1.09 \mathrm{E}- \\
11\end{array}$ \\
\hline \multicolumn{7}{|c|}{ Protein degradation } \\
\hline Unigene0064302 & cathepsin 0 & 3.062 & 1.468 & -1.061 & $\begin{array}{l}1.07 \mathrm{E}- \\
07\end{array}$ & $\begin{array}{l}1.06 \mathrm{E}- \\
06\end{array}$ \\
\hline Unigene0054503 & Cathepsin F & 25.301 & 6.568 & -1.946 & $\begin{array}{l}4.47 \mathrm{E}- \\
161\end{array}$ & $\begin{array}{l}5.86 \mathrm{E}- \\
159\end{array}$ \\
\hline Unigene0069862 & $\begin{array}{l}\text { Calpain-1 catalytic } \\
\text { subunit }\end{array}$ & 0.424 & 0.119 & -1.827 & $\begin{array}{l}2.86 \mathrm{E}- \\
06\end{array}$ & $\begin{array}{l}2.30 \mathrm{E}- \\
05\end{array}$ \\
\hline Unigene0065029 & Calpain-3 & 3.497 & 0.319 & -3.453 & $\begin{array}{l}7.02 \mathrm{E}- \\
14\end{array}$ & $\begin{array}{l}1.29 \mathrm{E}- \\
12\end{array}$ \\
\hline Unigene0029262 & calpain 5 & 3.229 & 1.140 & -1.502 & $\begin{array}{l}6.28 \mathrm{E}- \\
07\end{array}$ & $\begin{array}{l}5.58 \mathrm{E}- \\
06\end{array}$ \\
\hline Unigene0064726 & $\begin{array}{l}\text { E3 ubiquitin-protein } \\
\text { ligase CBL }\end{array}$ & 1.302 & 0.288 & -2.177 & $\begin{array}{l}4.70 \mathrm{E}- \\
06\end{array}$ & $\begin{array}{l}3.66 \mathrm{E}- \\
05\end{array}$ \\
\hline Unigene0047859 & $\begin{array}{l}\text { ubiquitin carboxyl- } \\
\text { terminal hydrolase } \\
\text { CYLD isoform X1 }\end{array}$ & 1.511 & 0.426 & -1.827 & $\begin{array}{l}1.42 \mathrm{E}- \\
04\end{array}$ & $\begin{array}{l}8.18 \mathrm{E}- \\
04\end{array}$ \\
\hline nigene0048496 & $\begin{array}{l}\text { E3 ubiquitin-protein } \\
\text { ligase SIAH1 }\end{array}$ & 1.643 & 0.545 & -1.594 & $\begin{array}{l}7.69 \mathrm{E}- \\
08\end{array}$ & $\begin{array}{l}7.72 \mathrm{E}- \\
07\end{array}$ \\
\hline Unigene0037497 & $\begin{array}{l}\text { ubiquitin carboxyl- } \\
\text { terminal hydrolase } 8\end{array}$ & 3.049 & 1.497 & -1.026 & $\begin{array}{l}3.54 \mathrm{E}- \\
16\end{array}$ & $\begin{array}{l}7.52 \mathrm{E}- \\
15\end{array}$ \\
\hline Unigene0006529 & $\begin{array}{l}\text { ubiquitin- } \\
\text { conjugating enzyme } \\
\text { E2R } 2\end{array}$ & 13.000 & 2.437 & -2.415 & $\begin{array}{l}3.04 \mathrm{E}- \\
51\end{array}$ & $\begin{array}{l}1.77 \mathrm{E}- \\
49\end{array}$ \\
\hline
\end{tabular}

KEGG analysis obtained 25 pathways, among which enriched the most differentially expressed genes were protein processing in endoplasmic reticulum $(119,3.77 \%)$, ubiquitin mediated proteolysis (101, $3.2 \%$ ) and RNA transport $(91,2.88 \%)$, respectively (Table 4). The results were confirmed by RT-PCR, proving that the genes expression difference and transcriptome results had the same trend (Fig. 4). 


\begin{tabular}{|c|c|c|c|c|}
\hline $\begin{array}{l}\text { Pathway } \\
\text { ID }\end{array}$ & Pathway & DEGs with pathway annotation & $\begin{array}{l}\text { All genes } \\
\text { with } \\
\text { pathway } \\
\text { annotation }\end{array}$ & P-value \\
\hline ko03050 & Proteasome & $42(1.33 \%)$ & $73(0.37 \%)$ & 5.69E-16 \\
\hline ko03008 & $\begin{array}{l}\text { Ribosome } \\
\text { biogenesis in } \\
\text { eukaryotes }\end{array}$ & $62(1.96 \%)$ & $\begin{array}{l}168 \\
(0.85 \%)\end{array}$ & $3.04 \mathrm{E}-11$ \\
\hline ko04141 & $\begin{array}{l}\text { Protein processing } \\
\text { in endoplasmic } \\
\text { reticulum }\end{array}$ & $119(3.77 \%)$ & $435(2.2 \%)$ & 7.21E-10 \\
\hline ko04120 & $\begin{array}{l}\text { Ubiquitin mediated } \\
\text { proteolysis }\end{array}$ & $101(3.2 \%)$ & $357(1.8 \%)$ & 2.01E-09 \\
\hline ko00240 & $\begin{array}{l}\text { Pyrimidine } \\
\text { metabolism }\end{array}$ & $58(1.84 \%)$ & $\begin{array}{l}189 \\
(0.95 \%)\end{array}$ & 2.84E-07 \\
\hline ko04142 & Lysosome & $78(2.47 \%)$ & $\begin{array}{l}282 \\
(1.42 \%)\end{array}$ & 3.67E-07 \\
\hline ko04140 & $\begin{array}{l}\text { Regulation of } \\
\text { autophagy }\end{array}$ & $20(0.63 \%)$ & $43(0.22 \%)$ & 2.44E-06 \\
\hline ko03030 & DNA replication & $24(0.76 \%)$ & $60(0.3 \%)$ & $6.70 \mathrm{E}-06$ \\
\hline ko03430 & Mismatch repair & $20(0.63 \%)$ & $46(0.23 \%)$ & $8.78 \mathrm{E}-06$ \\
\hline ko03420 & $\begin{array}{l}\text { Nucleotide excision } \\
\text { repair }\end{array}$ & $28(0.89 \%)$ & $78(0.39 \%)$ & $1.38 \mathrm{E}-05$ \\
\hline ko03013 & RNA transport & $91(2.88 \%)$ & $\begin{array}{l}383 \\
(1.94 \%)\end{array}$ & 4.08E-05 \\
\hline ko04974 & $\begin{array}{l}\text { Protein digestion } \\
\text { and absorption }\end{array}$ & $44(1.39 \%)$ & $\begin{array}{l}177 \\
(0.89 \%)\end{array}$ & 0.001422099 \\
\hline ko03410 & $\begin{array}{l}\text { Base excision } \\
\text { repair }\end{array}$ & $20(0.63 \%)$ & $66(0.33 \%)$ & 0.002557437 \\
\hline ko00860 & $\begin{array}{l}\text { Porphyrin and } \\
\text { chlorophyll } \\
\text { metabolism }\end{array}$ & $17(0.54 \%)$ & $54(0.27 \%)$ & 0.003361358 \\
\hline ko03020 & RNA polymerase & $18(0.57 \%)$ & $60(0.3 \%)$ & 0.004613781 \\
\hline ko04130 & $\begin{array}{l}\text { SNARE interactions } \\
\text { in vesicular } \\
\text { transport }\end{array}$ & $14(0.44 \%)$ & $45(0.23 \%)$ & 0.008341413 \\
\hline ko00230 & Purine metabolism & $71(2.25 \%)$ & $\begin{array}{l}341 \\
(1.72 \%)\end{array}$ & 0.009785118 \\
\hline
\end{tabular}




\begin{tabular}{|c|c|c|c|c|}
\hline $\begin{array}{l}\text { Pathway } \\
\text { ID }\end{array}$ & Pathway & DEGs with pathway annotation & $\begin{array}{l}\text { All genes } \\
\text { with } \\
\text { pathway } \\
\text { annotation }\end{array}$ & P-value \\
\hline ko05414 & $\begin{array}{l}\text { Dilated } \\
\text { cardiomyopathy }\end{array}$ & $80(2.53 \%)$ & $\begin{array}{l}398 \\
(2.01 \%)\end{array}$ & 0.01530128 \\
\hline ko03040 & Spliceosome & $71(2.25 \%)$ & $\begin{array}{l}353 \\
(1.78 \%)\end{array}$ & 0.02097551 \\
\hline ko00471 & $\begin{array}{l}\text { D-Glutamine and D- } \\
\text { glutamate } \\
\text { metabolism }\end{array}$ & $6(0.19 \%)$ & $15(0.08 \%)$ & 0.0223566 \\
\hline ko00908 & Zeatin biosynthesis & $2(0.06 \%)$ & $2(0.01 \%)$ & 0.02543888 \\
\hline ko05410 & $\begin{array}{l}\text { Hypertrophic } \\
\text { cardiomyopathy } \\
\text { (HCM) }\end{array}$ & $77(2.44 \%)$ & $\begin{array}{l}393 \\
(1.99 \%)\end{array}$ & 0.02970835 \\
\hline ko04712 & $\begin{array}{l}\text { Circadian rhythm - } \\
\text { plant }\end{array}$ & $4(0.13 \%)$ & $9(0.05 \%)$ & 0.04156557 \\
\hline ko00900 & $\begin{array}{l}\text { Terpenoid } \\
\text { backbone } \\
\text { biosynthesis }\end{array}$ & $7(0.22 \%)$ & $22(0.11 \%)$ & 0.04928443 \\
\hline ko04920 & $\begin{array}{l}\text { Adipocytokine } \\
\text { signaling pathway }\end{array}$ & $36(1.14 \%)$ & $\begin{array}{l}172 \\
(0.87 \%)\end{array}$ & 0.04951438 \\
\hline Gene & Primers & Sequences $\left(5^{\prime}-3^{\prime}\right)$ & & \\
\hline \multirow[t]{2}{*}{ Hsp90ß } & RT-HSP90ß-F & CGACTTAGAAACGACTACCACACG & & \\
\hline & RT-HSP90ß-R & CAGCCTGGAATGCAAAGGTCT & & \\
\hline \multirow[t]{2}{*}{ GHR2 } & RT-GHR2-F & CGCTGCTGAATGTGAGTTTGAC & & \\
\hline & RT-GHR2-R & CCCGAACCTCGTGATTGATG & & \\
\hline \multirow[t]{2}{*}{ IGFR1 } & RT-IGFR1-F & GCTACGTGAAGATCCGCCATT & & \\
\hline & RT-IGFR1-R & GCTGCAAGTTCTGGTTGTCCA & & \\
\hline \multirow[t]{2}{*}{ MyoD } & RT-MyoD-F & TTCTCAGAGGCTCCAAACGG & & \\
\hline & RT-MyoD-R & GCTCCACGATGCTGGACAGA & & \\
\hline \multirow[t]{2}{*}{ Mhc } & RT-Mhc-F & TTGTCCGTTGCCTGATTCCTA & & \\
\hline & RT-Mhc-R & CTTCCAGCACACCGTTACACC & & \\
\hline Mlc & RT-Mlc-F & АACСССТССАATGACGACA & & \\
\hline
\end{tabular}




\begin{tabular}{|c|c|c|c|c|}
\hline $\begin{array}{l}\text { Pathway } \\
\text { ID }\end{array}$ & Pathway & DEGs with pathway annotation & $\begin{array}{l}\text { All genes } \\
\text { with } \\
\text { pathway } \\
\text { annotation }\end{array}$ & P-value \\
\hline & RT-Mlc-R & AATCTCAGGCTCAGTCATCTTCTC & & \\
\hline \multirow[t]{2}{*}{ Myf6 } & RT-Myf6-F & AGACCAACCCTTATCTTTTCAATG & & \\
\hline & RT-Myf6-R & CGGTCTCGGACGGAACATTAT & & \\
\hline \multirow[t]{2}{*}{ Troponin } & RT-Troponin-F & GGGCTCCAAACACACAGTCAAC & & \\
\hline & RT-Troponin-R & GCCTTGTCCTCAATGTTCTTACG & & \\
\hline \multirow[t]{2}{*}{ 4ebp } & RT-4ebp-F & TCACCATCCACGATTCTGCTC & & \\
\hline & RT-4ebp-R & АССTCCTGGCGTAGTGCTGA & & \\
\hline \multirow[t]{2}{*}{ 18S RNA } & RT-18S-F & CTGAGAAACGGCTACCACATCC & & \\
\hline & RT-18S-R & GCACCAGACTTGCCCTCCA & & \\
\hline
\end{tabular}

Table.4 The pathway analysis of different expression genes between underweight and overweight in Siniperca chuatsi

Table. 5 Primer sequences for Hsp90ß, GHR2, IGFR1, MyoD, Mhc, Mlc, Myf6, Troponin, 4ebp and 18S RNA

\section{The expression growth-related genes in different periods}

The muscle growth-related genes screened in RNA-Seq were studied in different family and period to identify the expression and regulatory mechanisms. In two periods of two families, the expression of MyoD in L was always greater than S, but for the expression of IGFR1, 4ebp, and Myf6 in S fish was higher. Along with the increased culture cycle (5-month old), the expression levels of Mhc and Mlc in S revealed an upward trend comparing with L (Fig. $5 \mathrm{Mhc}$ and Mlc).

\section{Changes in body weight during compensatory growth}

The SGR in different time intervals was calculated (Fig. 6A) and the weight of fish in two groups was reflected at seven time points and curves were drawn (Fig. 6B). In the first week, the weight of the experimental group decreased markedly following the induction of starvation, as indicated by a negative SGR (-0.98) which reached the lowest (-2.62) in the second week. In the third week, the body weight loss slowed down (SGR - 0.64). During the following week of re-feeding, the weight of the experimental group increased rapidly and resulted in a positive of SGR (2.99), which was significantly higher than $(P<0.01)$ that in the control group. The elevated SGR that characterizes compensatory growth subsequently declined back to low level during the 2 weeks of realimentation, but the SGR of experimental groups was 
higher than $(P>0.05)$ that in the control group (Fig. 6A). The bodyweight difference of experiment and controls ultimately was no significant difference, indicating that the experimental groups achieved complete compensatory growth after re-feeding.

\section{Effect of re-feeding to expression of related-growth genes}

During starvation, the expression of GHR2, IGFR1 and 4ebp was up-regulated, and the difference of expression increased with the increase of starvation time, and the expression was close to that of the control group following re-feeding (Fig. 7). The expression levels of Mhc, Mlc, troponin and MyoD in starvation revealed the descent tendency, however, there was no significant difference in Myf6 expression (Fig. 7).

\section{Discussion}

The growth and development of vertebrates are mainly mediated through the GH-IGF system. Especially in teleost fish, the multiple forms of GHRs, and IGFRs have been described. However, they have distinct functions and expression patterns in various fish tissues [22]. In tilapia, GHR2 participates in growth and metabolism and is highly expressed in liver and muscle,while GHR1 expression is higher in liver [23]. In seabream and rainbow trout, GHR2 expression is much higher than GHR1 in numerous tissues such as muscle, pituitary, kidney and gonad [24, 25]. Interestingly, although GHR expression is affected by GH in many other fish, the opposite effects are found may due to the different expression levels. The growth responses are enhanced in loaches [26] and GH-transgenic salmon [27] and restrained in tilapia [28] and carp [29]. The weight and thick muscle fibers of GH/GHR-transgenic zebrafish is lower than the other genotypes [30]. In our experiments, however, both the enhancement and inhibition of growth occurred under different conditions, respectively. With the change of time, the expression of GHR2 among different sizes of individuals showed no significant difference (Fig. 5 GHR2), indicating that the stable expression of GHR2 was crucial to promoting growth and development. During starvation, high expression of GHR on the surface of muscle cells can save protein consumption [23], which also has been reported in gilthead sea bream and rainbow trout $[22,31]$. Therefore, in S.chuatsi, GHR2 appears to inhibit growth through significant high expression during starvation (Fig. 7 GHR2) and plays a physiologically significant role in muscle metabolism, involving in the mobilization of muscle energy stores.

IGFRs can bind to IGF-1, IGF-2 and insulin, and the affinity for insulin is much lower than for IGFs in all species [32]. Furthermore, in contrast to the situation in mammals, the IGFR1 of fish muscle is greater abundance than insulin receptors (IR) [32], indicating that IGFR1 is more relevant to the regulation of muscle function than IR in fish [33], involving promoting growth, enhancing protein, increasing cell proliferation and reducing protein degradation [34]. IGFR1 was highly expressed in S at 3-month old (Fig. 5 IGFR1) $(P<0.05)$, suggesting IGFR1 played a more essential role for $S$ over $L$ in muscle, such as participating in and promoting the growth of muscle. Interestingly, prolonged fasting results in significantly reduced IGF-1 mRNA in the liver and muscle of numerous fish species [35-37], whereas IGFR1 increased significantly $[13,35,38]$. In this study, the IGFR1 expression markedly rose during fasting 
(Fig. 7 IGFR1), illustrating that IGFR1 expression will increase to restrict IGF-I during starvation, which is probably related to the anti-apoptotic effects reported in mammals [38].

Phosphorylated of protein kinase $B$ (PKB) is controlled by the metabolic pathway regulated by IGFR1, and PKB can mediate the AKT/mTOR/p70S6K pathway to facilitate protein synthesis and cell growth [3941]. Meanwhile, mTOR can regulate translation by 4ebp [42], and the phosphorylation of 4ebp releases elF4E to stimulate translation initiation [43]. elF4E is able to enhance the translation of mRNAs, implicating in cell proliferation and growth [44], but it is hypothesized that overexpression of elF4E leads to the deregulation of translational and cellular homeostasis [45]. However, the family of 4ebps can inhibite the assembly of elF4F complex [45]. Thus, 4ebp inhibits cell growth and revert the transformed phenotype of elF4E-overexpressing cell [45], which may save energy and prevent the malignant transformation of cells during starvation by significant expression (Fig. 7 4ebp). In conclusion, we speculate that the expression of upstream IGFR1 will promote the expression of downstream 4ebp through the above-mentioned pathways in the case of starvation, so as to cope with the food restriction. In compensatory growth experiments, the expression of IGFR1 and 4ebp was consistent (Fig. 7 IGFR1 and 4ebp), proving the hypothesis, but further research is needed on specific regulatory mechanisms. It has been reported that fasting promotes the metabolic actions of $\mathrm{GH}$ rather than the growth-promoting actions [46], however, relevant aspects of researches in GHR2, IGFR1 and 4ebp are less. In the study, the functions of GHR2, IGFR1 and 4ebp also changed from growth promotion when food was abundant to growth inhibition in starvation, thus highlighting the metabolic functions of them.

Mhc expression is significantly related with growth rate [47-49], which also affects myofiber hyperplasia and indeterminate growth [50]. In this study, Mhc was highly expressed in S at 5-month old (Fig. $5 \mathrm{Mhc}$ ) $(P<0.05)$, and transcriptome results also showed that the growth rate of small fish was high, suggesting that Mhc can promote the growth of $\mathrm{S}$ through its high expression. In larval stage of S.chuatsi, the high expression of Mlc regulates muscle formation and early development [51], which also influences the tail shaft swimming character at posterior area, needing more muscle fiber and protein [52]. The significant high expression of Mlc at 5-month old in S (Fig. $5 \mathrm{Mlc}$ ) proved that muscle protein and muscle fiber synthesize quickly to meet physiological requirement. Taken together, as important components of myosin, Mhc and Mlc played a more positive role in $S$ comparing to $L$ at 5-month old. Interestingly, although they all enhanced the growth of S.chuatsi, the function time and action modes of myosin (Mlc, Mhc), GHR2, IGRF1 and 4ebp were different. GHR2 was expressed stably to promote growth (Fig. 5 GHR2), and IGFR1 had a more obvious promotion effects in S at 3-month old (Fig. 5 IGFR1). Furthermore, both myosin (Mlc, Mhc) and 4ebp facilitated more markedly in S at 5-month old (Fig. $5 \mathrm{Mlc}$, Mhc and 4ebp), showing all of them had their own temporal and spatial expression patterns in S.chuatsi.

Myosin, the primary protein of muscles, amounts to $50 \%$ of the muscle proteins [53]. Troponin as a complex protein is largely expressed in muscle and plays a vital role in muscle contraction [54, 55]. During fasting conditions, the markedly down-regulated of Mhc and Mlc indicated that muscle protein synthesis decreased (Fig. $7 \mathrm{Mhc}$ and Mlc), and muscle proteins may be used as the major energy source to maintain basic metabolism which limited growth and was consistent with the observed reduced weight 
(Fig. 6). In the meantime, because muscle breakdown and muscle protein synthesis were inhibited, muscle contraction and motor function were restrained, which was manifested as a significant decrease in troponin expression (Fig. 7 Troponin). After re-feeding, significant up-regulation of Mhc and Mlc was observed (Fig. $7 \mathrm{Mhc}$ and Mlc), showing that muscle protein was no longer used as the major energy source, and synthesis of muscle and rapid compensatory growth occurred, which resulted in increased weight [56]. As the normal synthesis and growth of muscle, muscle contraction was no longer inhibited and expression levels returned to normal (Fig. 7 Troponin).

MyoD is associated with myogenesis during developmental condition which plays a regulatory role in muscle hypertrophy and muscle mass $[57,58]$. Myf6 participates in myofiber differentiation by recruiting structural proteins [59]. From 3-month old to 5-month old, MyoD and Myf6 expression had a downward trend (Fig. $5 \mathrm{MyoD}$ and Myf6), which agreed with the experiment phenomenon of Zhu et al [60].It suggested that 3-month old may be a rapid growth stage for S.chuatsi, accompanying with an intense myoblast differentiation, which primarily contributed to the muscle growth [60]. What puzzled us is that both MyoD and Myf6 belong to the MRFs family, but the trends of expression results were opposite in $L$ and S (Fig. 5 MyoD and Myf6), and there was no significant difference, which may be influenced by the complex regulatory systems in vivo. It has been reported that the reduction in muscle weight may stimulate MRFs transcription [61]. And in mammals, satellite cells can express MyoD and Myf5 in response to muscle damage $[62,63]$. Interestingly, during the starvation period, the expression of MyoD fell to the lowest level and then increased following the weight loss. After re-feeding, the expression gradually decreased from the highest level, and during the whole process, the expression had a certain delayed (Fig. 7 MyoD). But, the expression of Myf6 was stable throughout the process. These phenomena indicated that MyoD had a sensory and regulatory effects on the weight loss and was conducive to the muscle growth and recovery for S.chuatsi.

\section{Conclusions}

In conclusion, numerous DEGs were identified, and several significant DEGs were chosen to explore the expression in different period and compensatory growth. These genes play an important role in muscle growth in S.chuatsi. This study expands our understanding of the mechanism of compensatory growth, and will provide a reference for muscle growth-related genes in S.chuatsi.

\section{Methods}

\section{Experimental animals}

In this study, all of S.chuatsi came from Foshan Bairong Aquatic Breeding CO., LTD. Three full-sib families $A, B$ and $C$ were constructed by artificial insemination. Each family contained 80 S.chuatsi in a separate tank. The experimental fish were fed under uniform conditions; they were provided adequate live fish as bait twice daily at 0900 and 1800 hours. The water temperature was maintained at $25-26^{\circ} \mathrm{C}$. After 
feeding 3 months in family A, 5S and $5 \mathrm{~L}$ was performed for RNA-sEq. For B and C families, $6 \mathrm{~L}$ and $6 \mathrm{~S}$ fish were selected from each family at 3-month old and 5-month old for real-time PCR.

\section{Tissue sampling}

All of the above experimental fish were anesthetized with tricaine methanesulfonate (MS-222, 100 mg/L) and sacrificed via decapitation for subsequent sampling, and muscle was removed immediately. The tissues were frozen in liquid nitrogen quickly, and stored at $-80{ }^{\circ} \mathrm{C}$ until use. Furthermore, each experiment was performed with three independent biological replicates.

\section{RNA extraction and library construction}

Total RNA was extracted from white muscle with E.Z.N.A. total RNA kit II and detected with the concentration and quality. To acquire the entire transcriptome information, and to find out the growthrelated DEGs, the muscle samples of family A were mixed with equal amount and then were divided into 2 RNA pools. PolyA mRNA was isolated by Beads with Oligo (dT) after total RNA was collected and interrupted to short fragments. Random hexamer-primer was used to synthesize the first-strand cDNA using the Qiaquick PCR Purification Kit (Qiagen). The second-strand cDNA was synthesized using buffer, dNTPs, RNaseH and DNA polymerase I, respectively (Invitrogen). Subsequently, short fragments were purified, enriched for end reparation and adding polyA, connected with sequencing adapters. After that, the suitable fragments were selected using agarose gel electrophoresis for the PCR amplification as templates. At last, the two cDNA library could be sequenced in BGI-Shenzhen using Illumina $\mathrm{HiSeq}^{\mathrm{TM}} 2000$.

\section{Illumina reads processing and assembly}

Clean reads were screened from raw reads gained from sequencing machines by removing adaptors, unknown nucleotides larger than 5\% and low quality reads (which the percentage of low Q-value $\leq 10$ base was more than 20\%) which would negatively affect following bioinformatics analysis. Firstly, program-Trinity combines reads with certain length of overlap to form longer fragments without $\mathrm{N}$, which are called contigs. Then, these contigs were taken into further process of sequence cluster with sequence clustering software to form longer sequences without N, which are defined as unigenes.

\section{Functional annotation and classification}

The unigenes sequences were firstly aligned with a series of public databases, such as the non-redundant protein database, the Cluster of Orthologous Groups (COG) of protein database, the Kyoto Encyclopedia of Genes and GenBank non-redundant (NR) database and Swiss-Prot database, using BLASTx (Evalueb10-5) and BLAST (E-valueb10 ${ }^{-10}$ ), respectively. The KEGG database helped study complicated biological behaviors of genes. With KEGG annotation we can get Pathway annotation of unigenes. GO annotation of unigenes was acquired by Blast2GO program. And then unigenes were classified into different GO functional cluster using WEGO software. ESTScan software was used to decide the direction of sequences which were not aligned to the above databases. GO has three ontologies: molecular function, cellular component and biological process. The basic unit of GO is GO-term. Every GO-term belongs to a type of ontology. 


\section{Differential genes expression analysis}

The genes expression was calculated by the numbers of reads that mapped to the reference sequence and every gene. All genes expression levels were calculated by using the formula RPKM method and the RPKM of genes can be used for comparing between different samples. Different expression genes were carried out GO function analysis to understand its function. False Discovery Rate (FDR) was used to determine the threshold of P-value which corresponds to differential gene expression test in multiple tests. FDR $\leq 0.001$ and the absolute value of $\log _{2}{ }^{\text {Ratio }} \geq 1$ is used as the threshold to judge the significance of gene expression difference.

\section{RT-PCR analysis}

Corresponding primers were designed to vertify the results (Table 5). 6 DEGs were selected as the verification genes to confirm the reliability of data obtained by RNA-seq, in which 18SrRNA was used as a reference gene which was no evident difference in different samples of S. chuatsi. Quantitative Fluorescence PCRassay was performed with LightCycler ${ }^{\circledR} 480$ II Real-Time PCR System (Roche), and the kits were SYBR ${ }^{\circledR}$ Premix Ex TaqTM II (Tli RNaseH Plus) (TaKaRa, Japan), with 384-well plates. In each reaction system, there were $10 \mathrm{ul}$ including the first-strand cDNA, $250 \mathrm{nM}$ primers, and $5 \mu$ I SYBR Green PCR Master Mix (TaKaRa, Japan). Each reaction was repeated 3 times. And the relative expression levels were calculated by the $2^{-\Delta C t}$ method.

\section{The synthesis of cDNA and Real-time PCR detection}

cDNA was synthesized from muscle in $B$ and $C$ familes with PrimeScript ${ }^{\circledR} R T$ reagent Kit with gDNA Eraser (Perfect Real Time). The specific primers for the RT-PCR were designed based on selected growthrelated genes using the Primer Premier5.0. Real-time PCR was performed according to TAKARA's SYBR Premix Ex TaqTM II (Tli RNaseH Plus).

\section{Fasting and re-feeding experiments}

A total of 80 experimental fish from one family ( $300 \pm 30 \mathrm{~g}$, body weight) were randomly divided into control and experimental groups that each included four repeated subgroups. Each subgroup contained 20 in a separate tank. The water temperature was maintained at $25-26^{\circ} \mathrm{C}$, and the compensatory growth experiment lasted for six weeks. During an initial 3 weeks of fasting, food was withheld from the experimental group, while that of the control group was maintained at a normal level. After this, both the experimental group and the control group were fed continuously during the following 3 weeks. Seven sampling time points $(0-6)$ were set throughout the experiment. At each sampling time point, six S. chuatsi in a pond were randomly selected from each group and sampled following anaesthesia with MS$222(100 \mathrm{mg} / \mathrm{L})$. Sampling time points $0,1,2$ and 3 represented $\mathrm{S}$. chuatsi that had been fasted for 0, 1, 2 and 3 weeks, respectively. Sampling time points 4, 5 and 6 represented the fish that were re-fed continuously for 1, 2 and 3 weeks after starvation, respectively. The fish were fed twice a day and weighed every week, and weights were used to calculated The Specific growth rate (SGR). SGR means ((In W $2-W 1) /(T 2-T 1) \times 100)$, where W 2 is the weight at the end of the growth interval and W 1 is the 
weight at the beginning of the growth interval, while T 2 -T 1 represents the duration (days) of the growing interval. The muscle samples collected from S. chuatsi was rapidly frozen in liquid nitrogen and stored at $-80^{\circ} \mathrm{C}$ and samples were used for real-time PCR analysis.

\section{Statistical analyses}

SPSS version 18.0 was used for the analyses in the study, Trukey 'test was applied to compare the significant differences of the expression of the growth-related genes. The level of significance for all statistical tests was set at $5 \%(P<0.05)$.

\section{Abbreviations}

DEGs

Differentially expressed genes

RNA-seq

RNA-sequencing

GO

Gene ontology

KEGG

Kyoto encyclopedia of genes and genomes

$\mathrm{S}$

Small individuals

L

Large individuals

SGR

Specific growth rate

Mhc

Myosin heavy chain

Mlc

Myosin light chain

MRFs

Myogenic Regulatory Factors

IGF

insulin-like growth factor

IGFR

insulin-like growth factor receptors

$\mathrm{GH}$

growth hormone

GHR

$\mathrm{GH}$ receptors

4ebp 
eukaryotic translation initiation factor $4 \mathrm{E}$-binding protein;

Hsp90ß

heat shock protein hsp90 beta

SMYD

SET and MYND domain-containing protein 1 isoform 2

MyoD

Myoblast determination protein

Myf6

Myogenic factor 6

\section{Declarations}

\section{Ethics approval and consent to participate}

Mandarin fish experiments were approved by the Institutional Animal Care and Use Committee of Sun Yat-sen University and performed in accordance with the guidelines for experimental animals established by this committee.

\section{Consent for publication}

Not applicable.

\section{Availability of data and material}

All data generated or analysed during this study are included in this published article.

\section{Competing interests}

The authors declare that they have no competing interests.

\section{Funding}

This research was supported by the National Key R\&D Program of China (2018YFD0901203), the Research in Spreading and Breeding Feedstuff of a New Species of Siniperca chuatsix Siniperca scherzeri (Yuenong 2019A2), and the Results Transformation and Achievement Extension of Siniperca chuatsix Siniperca scherzeri. None of the funding bodies participated in the design of the study, collection, analysis, and interpretation of data, or writing the manuscript. 


\section{Authors' contributions}

We confirm that the manuscript has been read and approved by all named authors and that there are no other persons who satisfied the criteria for authorship but are not listed. GFL conceived the study; GfL and XGL designed the experiments; XGL, SZ, HL, SB collected the samples; XGL did the experiments; XGL \&SZ , DLG prepared the figures and tables; XGL \& GFL drafted the work or revised it critically for important content; GPW, XLC, XPZ, SL, YQS, HDY made other contributions.

\section{Acknowledgments}

We would like to thank the aquatic breeding farm in Foshan for providing mandarin fish and local fishermen for assistance in collection of samples, professor Guifeng Li for his invaluable feedback on drafts of this manuscript, Dingli Guo and Han Lai for their assistance with mandarin fish husbandry.

\section{Affiliations}

${ }^{1}$ Guangdong Province Key Laboratory for Aquatic Economic Animals, School of Life Sciences, Sun YatSen University, Guangzhou, 510006, China

${ }^{2}$ Guangdong Provincial Engineering Technology Research Center for Healthy Breeding of Important Economic Fish, Guangzhou, 510006, China

${ }^{3}$ Southern Marine Science and Engineering Guangdong Laboratory, Zhuhai, 519082, China

\section{Corresponding author}

Correspondence to Guifeng $\mathrm{Li}$

\section{References}

1. Riley LG, Richman NH, Tetsuya H, Grau Gordon E. Activation of the growth hormone/insulin-like growth factor axis by treatment with 17 alpha-methyltestosterone and seawater rearing in the tilapia, Oreochromis mossambicus. Gen Comp Endocrinol. 2002;127:285-92.

2. De-Santis C, Jerry DR. Candidate growth genes in finfish - Where should we be looking? Aquaculture. 2007;272:22-38.

3. Devlin RH, Dionne S, Tymchuk WE, Rise ML, Benjamin G. Domestication and growth hormone transgenesis cause similar changes in gene expression in coho salmon (Oncorhynchus kisutch). Proc Natl Acad Sci U S A. 2009;106:3047-52. 
4. Rowlerson A, Veggetti A. 5 - Cellular Mechanisms of Post-Embryonic Muscle Growth in Aquaculture Species. Fish Physiol. 2001;18:103-40.

5. Steinbacher P, Haslett JR, Six M, Gollmann HP, Sänger AM, Stoiber W. Phases of myogenic cell activation and possible role of dermomyotome cells in teleost muscle formation. Dev Dyn. 2010;235:3132-43.

6. Veggetti A, Mascarello F, Scapolo PA, Rowlerson A, Carnevali MDC. Muscle growth and myosin isoform transitions during development of a small teleost fish, Poecilia reticulata (Peters) (Atheriniformes, Poeciliidae): a histochemical, immunohistochemical, ultrastructural and morphometric study. Anat Embryol. 1993;187:353-61.

7. Weatherley AH, Gill HS, Lobo AF. Recruitment and maximal diameter of axial muscle fibres in teleosts and their relationship to somatic growth and ultimate size. J Fish Biol. 2010;33:851-9.

8. Tian C, Li L, Liang XF, He S, Guo W, Lv L, et al. Identification of differentially expressed genes associated with differential body size in mandarin fish ( Siniperca chuatsi). Genetica. 2016;144:445-55.

9. Picha ME, Biga PR, Galt N, Mcginty AS, Gross K, Hedgpeth VS, et al. Overcompensation of circulating and local insulin-like growth factor-1 during catch-up growth in hybrid striped bass (Morone chrysops $\times$ Morone saxatilis ) following temperature and feeding manipulations. Aquaculture. 2014;428-429:174-83.

10. Nebo C, Portella MC, Carani FR, Almeida FLA De, Padovani CR, Carvalho RF, et al. Short periods of fasting followed by refeeding change the expression of muscle growth-related genes in juvenile Nile tilapia (Oreochromis niloticus ). Comp Biochem Physiol Part B. 2013;164:268-74.

11. Chauvigné F, Gabillard JC, Weil C, Rescan PY. Effect of refeeding on IGFI, IGFII, IGF receptors, FGF2, FGF6, and myostatin mRNA expression in rainbow trout myotomal muscle. Gen Comp Endocrinol. 2003;132:209-15.

12. Brogiolo . W, Stocker . H, Ikeya . T, Rintelen . F, Fernandez . R, Hafen . E. An evolutionarily conserved function of the Drosophila insulin receptor and insulin-like peptides in growth control. Curr Biol. 2001;11:213-21.

13. Montserrat N, Gabillard JC, Capilla E, Navarro MI, Gutiérrez J. Role of insulin, insulin-like growth factors, and muscle regulatory factors in the compensatory growth of the trout (Oncorhynchus mykiss ). Gen Comp Endocrinol. 2007;150:462-72.

14. Ali MA, Nicieza AG, Wootton RJ. Compensatory growth in fishes: A response to growth depression. Fish Fish. 2003;4:147-90.

15. Collins JE, White S, Searle SMJ, Stemple DL. Incorporating RNA-seq data into the zebrafish Ensembl genebuild. Genome Res. 2012;22:2067-78.

16. Liu S, Zhang Y, Zhou Z, Waldbieser G, Sun F, Lu J, et al. Efficient assembly and annotation of the transcriptome of catfish by RNA-Seq analysis of a doubled haploid homozygote. BMC Genomics. 2012;13:1-18. 10.1186/1471-2164-13-595. 
17. Sarropoulou . E, Galindo-Villegas . J, García-Alcázar . A, Kasapidis . P, Mulero . V. Characterization of European sea bass transcripts by RNA SEQ after oral vaccine against V. anguillarum. Mar Biotechnol. 2012;14:634-42.

18. Palstra AP, Sergi B, Erik B, Brittijn SA, Magnoni LJ, Henkel C V, et al. Deep RNA sequencing of the skeletal muscle transcriptome in swimming fish. PLoS One. 2013;8:e53171.

19. Dou Y, He S, Liang XF, Cai W, Wang J, Shi L, et al. Memory Function in Feeding Habit Transformation of Mandarin Fish (Siniperca chuatsi). Int J Mol Sci. 2018;19:1254.

20. Huang R, Zhang J, Zhu G, He J, Xie J. The core ubiquitin system of mandarin fish, Siniperca chuatsi, can be utilized by infectious spleen and kidney necrosis virus. Fish Shellfish Immunol. 2017;70:293301.

21. Wu N, Zhang X-Y, Huang B, Zhang N, Zhang X-J, Guo X, et al. Investigating the potential immune role of fish NCAMs: Molecular cloning and expression analysis in mandarin fish. Fish Shellfish Immunol. 2015;46:765-77. 10.1016/j.fsi.2015.08.006.

22. Saera-Vila A, Calduch-Giner JA, Pérez-Sánchez J. Duplication of growth hormone receptor (GHR) in fish genome: gene organization and transcriptional regulation of GHR type I and II in gilthead sea bream ( Sparus aurata ). Gen Comp Endocrinol. 2005;142:193-203.

23. Pierce AL, Fox BK, Davis LK, Visitacion N, Kitahashi T, Hirano T, et al. Prolactin receptor, growth hormone receptor, and putative somatolactin receptor in Mozambique tilapia: Tissue specific expression and differential regulation by salinity and fasting . Gen Comp Endocrinol. 2007;154:3140.

24. Jiao, B. The co-existence of two growth hormone receptors in teleost fish and their differential signal transduction, tissue distribution and hormonal regulation of expression in seabream. J Mol Endocrinol. 2006;36:23-40.

25. Very NM, Kittilson JD, Norbeck LA, Sheridan MA. Isolation, characterization, and distribution of two cDNAs encoding for growth hormone receptor in rainbow trout (Oncorhynchus mykiss). Comp Biochem Physiol Part B Biochem Mol Biol. 2005;140:615-28.

26. Nam YK, Noh JK, Cho YS, Cho HJ, Cho KN, Kim CG, et al. Dramatically accelerated growth and extraordinary gigantism of transgenic mud loach Misgurnus mizolepis. Transgenic Res. 2001;10:353-62.

27. R.H. Devlin, T.Y. Yesaki, C.A. Biagi, E.M.Donaldson, P. Swanson WKC. Extraordinary salmon growth. Nature. 1994;371:209-10.

28. Hernandez O, Guillen I, Estrada MP, Cabrera E, Fuente J de la. Characterization of transgenic tilapia lines with different ectopic expression of tilapia growth hormone. Mol Mar Biol Biotechnol. 1997;6:364-75.

29. Zhang P, Hayat M, Joyce C, Gonzalezvillaseñor LI, Lin CM, Dunham RA, et al. Gene transfer, expression and inheritance of pRSV-rainbow trout-GH cDNA in the common carp, Cyprinus carpio (Linnaeus). Mol Reprod Dev. 1990;25:3. 
30. Silva AC, Almeida D V, Nornberg BF, Figueiredo MA, Romano LA, Marins LF. Effects of Double Transgenesis of Somatotrophic Axis (GH/GHR) on Skeletal Muscle Growth of Zebrafish (Danio rerio). Zebrafish. 2015;12:408-13.

31. Gabillard J, Kamangar N B. Coordinated regulation of the GH/IGF system genes during refeeding in rainbow trout (Oncorhynchus mykiss). J Endocrinol. 2006;191:15-24.

32. Wood AW, Duan CH. Insulin-like growth factor signaling in fish. Int Rev Cytol. 2005;243:215-85.

33. Reinecke M, Björnsson BT, Dickhoff WW, McCormick SD, Navarro I, Power DM, et al. Growth hormone and insulin-like growth factors in fish: Where we are and where to go. 2005;142:20-4.

34. Radaelli G, Domeneghini C, Arrighi S, Bosi G, Patruno M, Funkenstein B. Localization of IGF-I, IGF-I receptor, and IGFBP-2 in developing Umbrina cirrosa (Pisces: Osteichthyes). Gen Comp Endocrinol. 2003;130:232-44.

35. Chen X, Wang G, Lu X, Xu P, Zeng S, Chen Z, et al. Molecular characterization and expression profiles of two insulin-like growth factor 1 receptors during fasting and re-feeding in Siniperca chuatsi. Fish Sci. 2019;85:349-60.

36. Pedroso FL, Jesus-Ayson EGT de, Cortado HH, Hyodo S, Ayson FG. Changes in mRNA expression of grouper (Epinephelus coioides) growth hormone and insulin-like growth factor I in response to nutritional status. Gen Comp Endocrinol. 2006;145:237-46.

37. Peterson BC, Waldbieser GC. Effects of fasting on IGF-I, IGF-II, and IGF-binding protein mRNA concentrations in channel catfish (Ictalurus punctatus). Domest Anim Endocrinol. 2009;37:0-83.

38. Yakar . S, Pennisi . P, Kim CH, Zhao . H, Toyoshima . Y, Gavrilova . O, et al. Studies involving the GHIGF axis: Lessons from IGF-I and IGF-I receptor gene targeting mouse models. J Endocrinol Invest. 2005;28 5 Suppl:19-22.

39. Bodine SC, Stitt TN, Gonzalez . M, Kline WO, Stover GL, Bauerlein . R, et al. Akt/mTOR pathway is a crucial regulator of skeletal muscle hypertrophy and can prevent muscle atrophy in vivo. Nat Cell Biol. 2001;3:1014-9.

40. Jiang BH, Aoki . M, Zheng JZ, Li . J, Vogt PK. Myogenic signaling of phosphatidylinositol 3-kinase requires the serine-threonine kinase Akt/protein kinase B. Proc Natl Acad Sci U S A. 1999;96:207781.

41. Sasai N, Miyazu AN. Involvement of PI3K/Akt/TOR pathway in stretch-induced hypertrophy of myotubes. Muscle Nerve. 2010;41:100-6.

42. Nissim H, Nahum S. Upstream and downstream of mTOR. Genes Dev. 2004;18:1926.

43. Stephan W, Robbie L, Hall MN. TOR signaling in growth and metabolism. Cell. 2006;124:471-84.

44. Mamane Y, Emmanuel P, Liwei R, Kaori Y, Wee LL, Nahum S. elF4E-from translation to transformation. Oncogene. 2004;23:3172-9.

45. Mamane Y, Petroulakis EIO, Sonenberg N. mTOR, translation initiation and cancer. Oncogene. 2006;25:6416-22. 
46. Norbeck LA, Kittilson JD, Sheridan MA. Resolving the growth-promoting and metabolic effects of growth hormone: Differential regulation of GH-IGF-I system components. 2007;151:332-41.

47. Churova M V, Meshcheryakova O V, Veselov AE, Nemova NN. Activity of enzymes involved in the energy and carbohydrate metabolism and the level of some molecular-genetic characteristics in young salmons ( Salmo salar L) with different age and weight. Ontogenez. 2015;46:304.

48. Dhillon RS, Esbaugh AJ, Wang YS, Tufts BL. Characterization and expression of a myosin heavychain isoform in juvenile walleye Sander vitreus. J Fish Biol. 2010;75:1048-62.

49. Overturf K, Hardy RW. Myosin expression levels in trout muscle: a new method for monitoring specific growth rates for rainbow trout Oncorhynchus mykiss (Walbaum) on varied planes of nutrition. Aquac Res. 2015;32:315-22.

50. Biga PR, Goetz FW. Zebrafish and giant danio as models for muscle growth: determinate vs. indeterminate growth as determined by morphometric analysis. Am J Physiol Regul Integr Comp Physiol. 2006;291:R1327-37.

51. Chu WY, Chen . J, Zhou RX, Zhao FL, Meng . T, Chen DX, et al. Characterization and ontogenetic expression analysis of the myosin light chains from the fast white muscle of mandarin fish Siniperca chuatsi. J Fish Biol. 2011;78:1225-38.

52. Patel JR, Diffee GM, Moss RL. Myosin regulatory light chain modulates the Ca2+ dependence of the kinetics of tension development in skeletal muscle fibers. Biophys J. 1996;70:2333-40.

53. Watabe S, Ikeda D. Diversity of the pufferfish Takifugu rubripes fast skeletal myosin heavy chain genes. Comp Biochem Physiol Part D Genomics Proteomics. 2006;1:28-34.

54. Fu CY, Lee HC, Tsai HJ. The molecular structures and expression patterns of zebrafish troponin I genes. Gene Expr Patterns. 2009;9:348-56.

55. Huang W, Zhang RX. Myofibrillogenesis in the developing zebrafish heart: A functional study of tnnt2. Dev Biol. 2009;331:237-49.

56. He L, Pei Y, Jiang Y, Li Y, Liao L, Zhu Z, et al. Global gene expression patterns of grass carp following compensatory growth. BMC Genomics. 2015;16:184.

57. Ahammad AKS, Asaduzzaman M, Asakawa S, Watabe S, Kinoshita S. Regulation of gene expression mediating indeterminate muscle growth in teleosts. Mech Dev. 2015;137:53-65.

58. Huang Y, Wen H, Zhang M, Hu N, Si Y, Li S, et al. DNA methylation status of MyoD and IGF-I gene correlated with its muscle growth during different development stages of Japanese flounder ( Paralichthys olivaceus ). Comp Biochem Physiol Part B Biochem Mol Biol. 2018; S1096495918300204.

59. Xie SQ, Mason PS, Stickland NC, Wilkes D, Goldspink G, Fauconneau B. Lower environmental temperature delays and prolongs myogenic regulatory factor expression and muscle differentiation in rainbow trout (Onchrhynchus mykiss) embryos. Differentiation. 2010;68:106-14.

60. Zhu X, Li YL, Liu L, Wang JH, Li HH, Wu P, et al. Molecular characterization of Myf5 and comparative expression patterns of myogenic regulatory factors in Siniperca chuatsi. Gene Expr Patterns Gep. 2016;20:1-10. 
61. Johansen KA, Overturf K. Quantitative Expression Analysis of Genes AffectingMuscle Growth During Development of Rainbow Trout( Oncorhynchus mykiss). Mar Biotechnol. 2005;7:576-87.

62. Hawke TJ, Garry DJ. Myogenic satellite cells: physiology to molecular biology. J Appl Physiol. 2001;91:534-51.

63. Smith CK, Janney MJ, Allen RE. Temporal expression of myogenic regulatory genes during activation, proliferation, and differentiation of rat skeletal muscle satellite cells. J Cell Physiol. 1994;159:379.

\section{Figures}

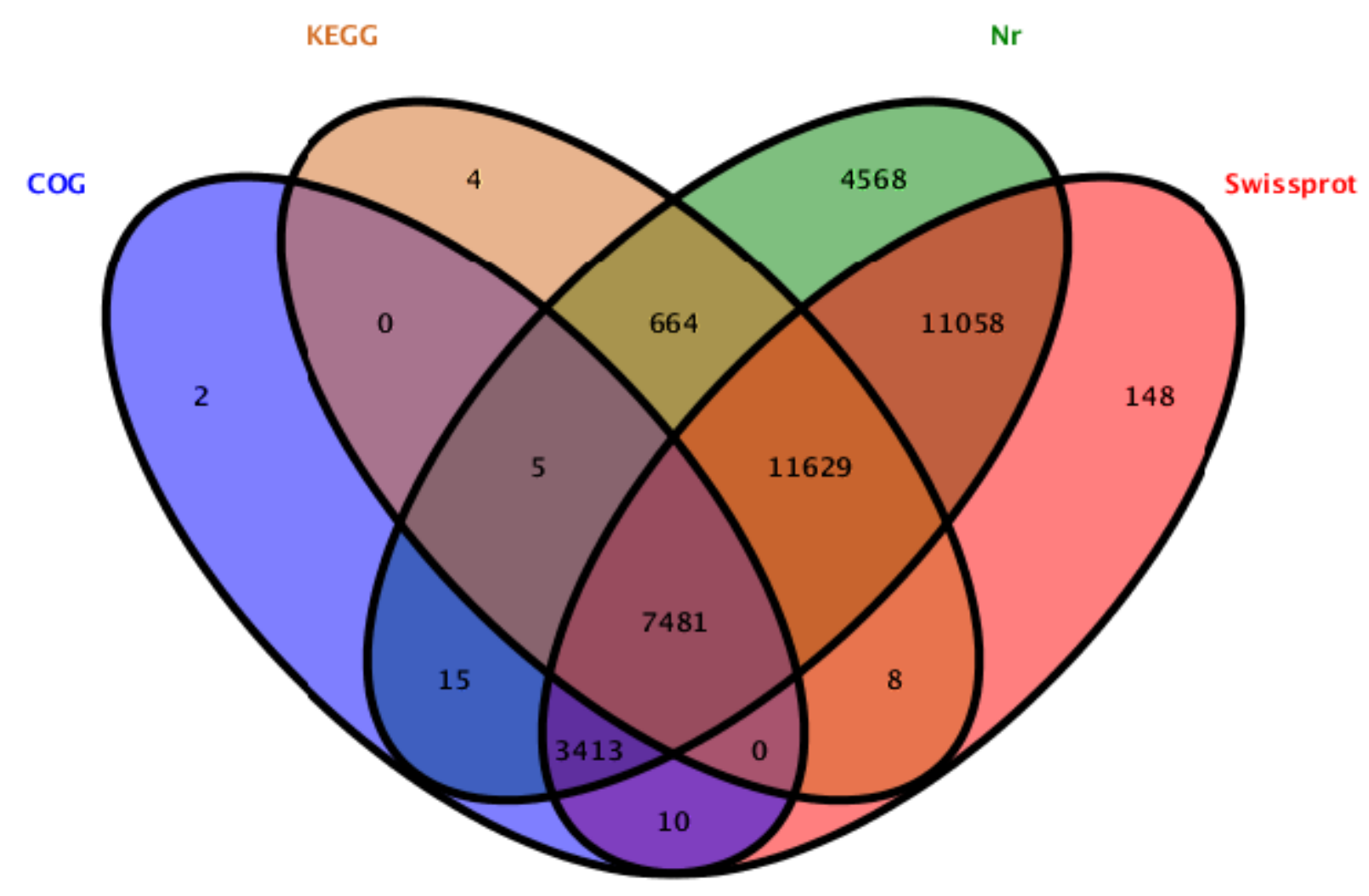

\section{Figure 1}

Detection of homologous genes in public databases. The numbers of annotated all-unigenes were indicated in the ellipses respectively. 


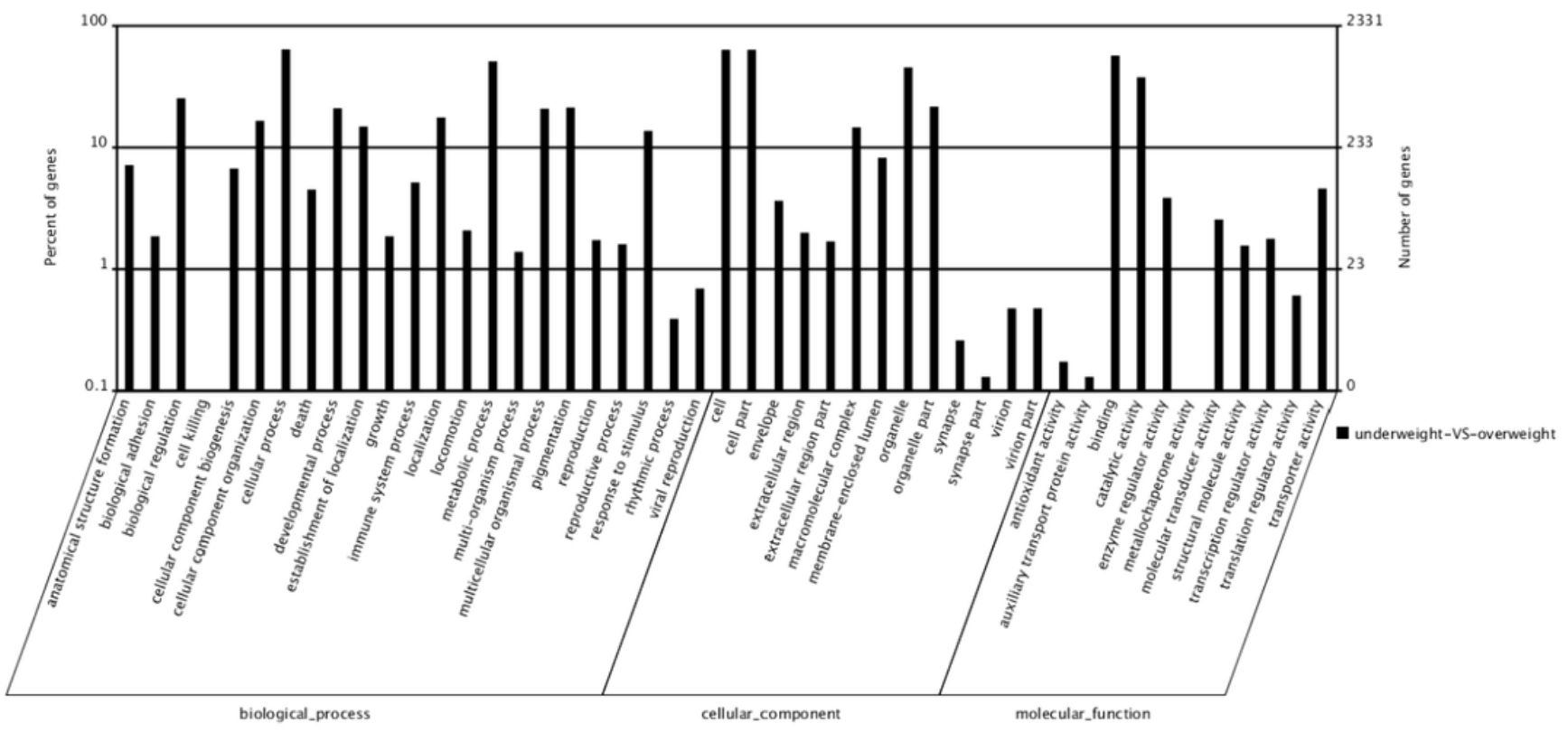

Figure 2

The number of different expression genes that the genes of large fish compared to the genes of small fish.

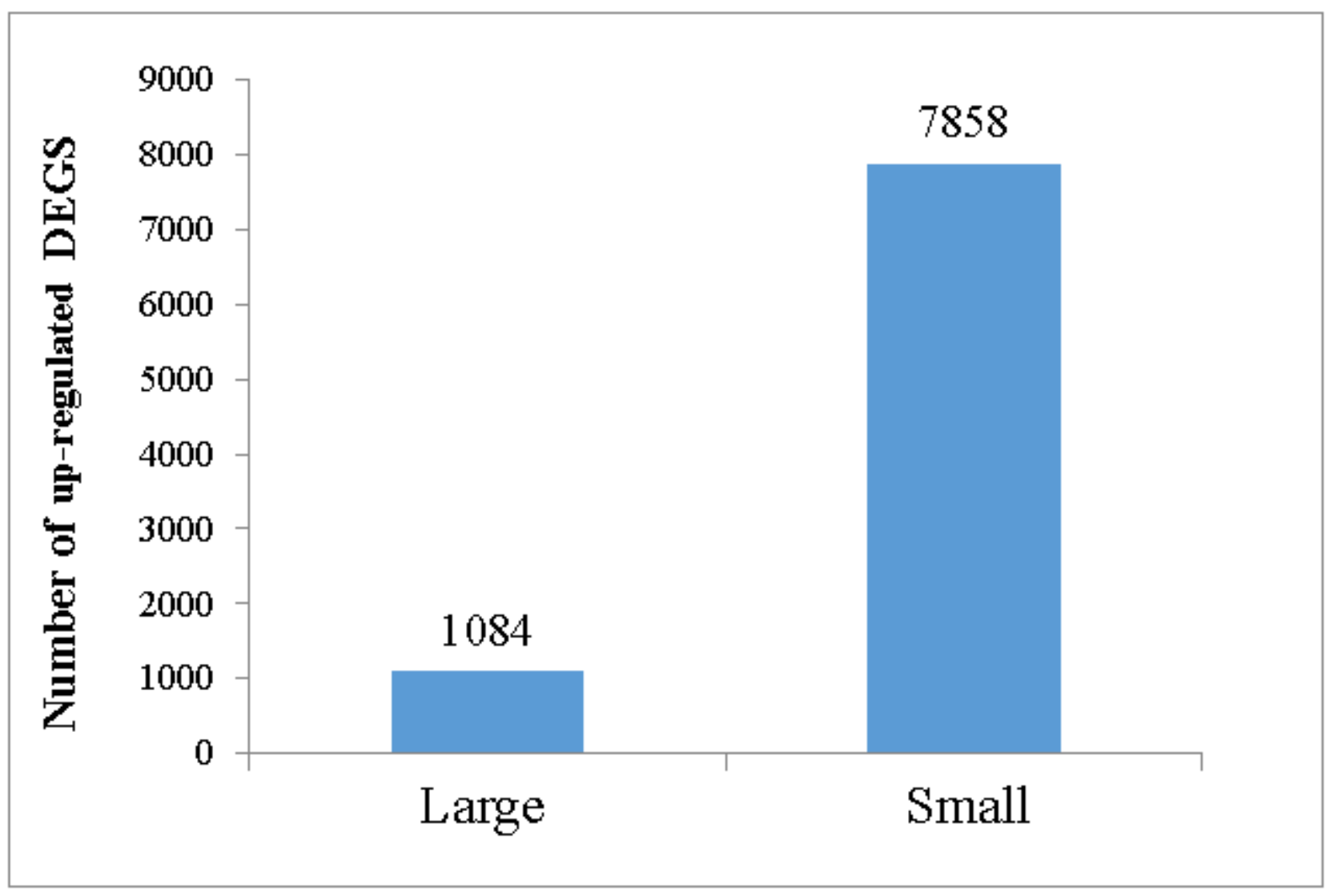


Figure 3

The GO analysis of different expression genes.
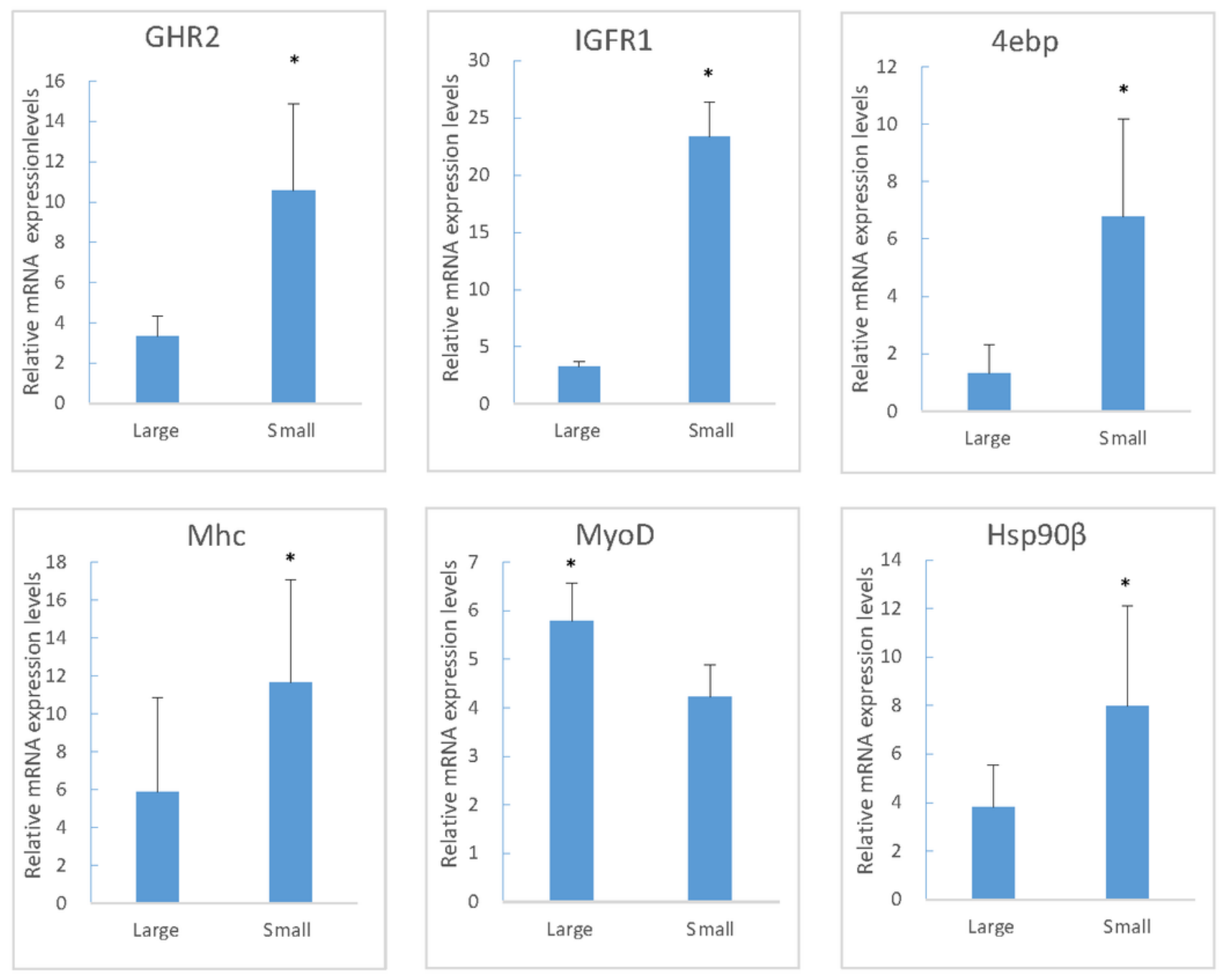

\section{Figure 4}

The RT-PCR analysis of gene expression in large and small fish. The y-axis indicates relative expression level between the samples of large and small fish using the Relative Quantitation. IGFR1: insulin-like growth factor receptor -1; GHR1: growth factor receptor-1; 4EBP: eukaryotic translation initiation factor 4Ebinding protein; Mhc: fast skeletal muscle myosin heavy chain; Hsp90ß: heat shock protein hsp90 beta (Hsp 90ß); SMYD: SET and MYND domain-containing protein 1 isoform 2, * indicate the differences between the two groups are significant $P<0.05(n=6)$. 

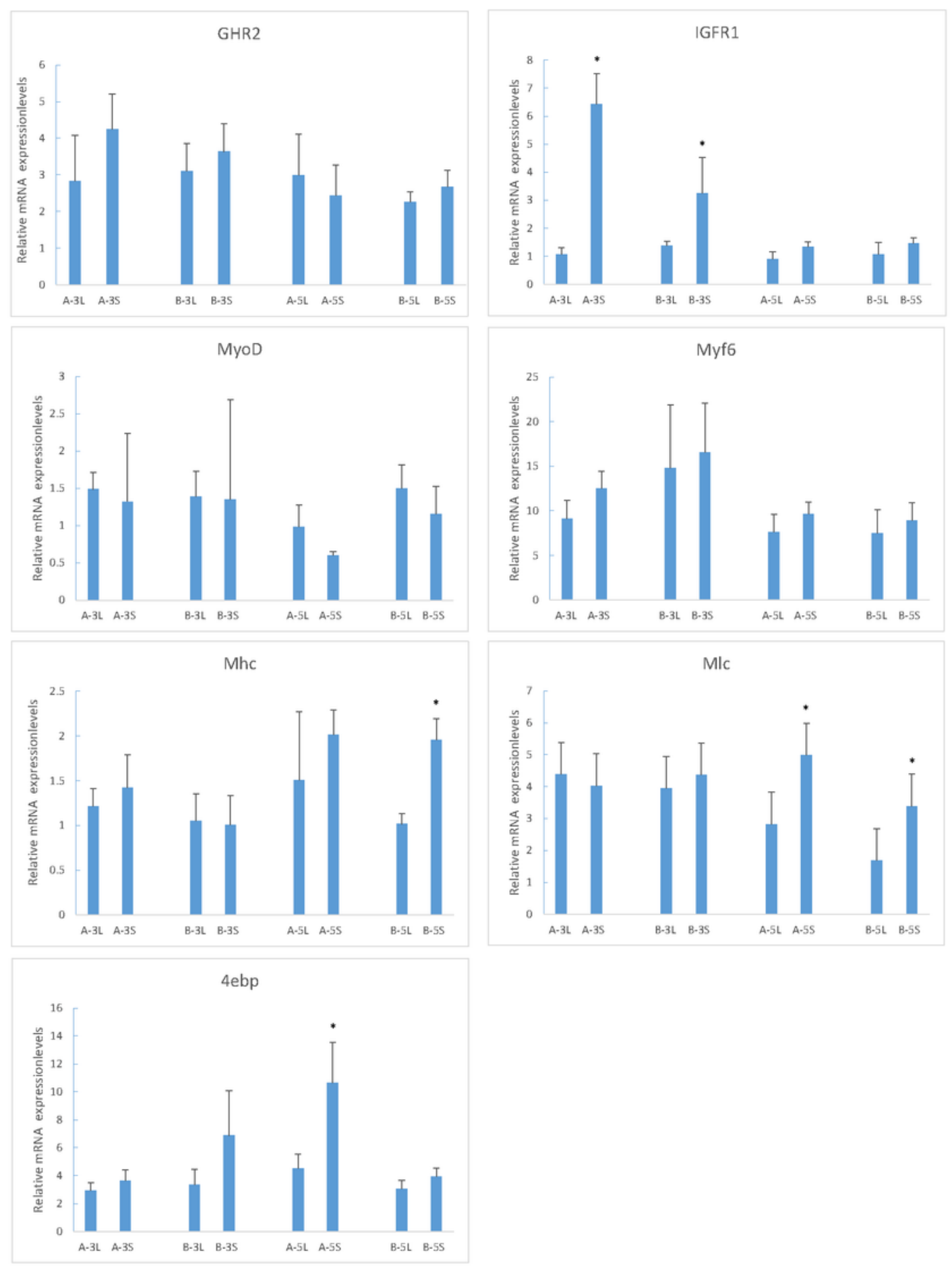

\section{Figure 5}

Relative expression of growth-related genes in mandarin fish with different growth traits. 18S was used as a housekeeping gene. All data are represented as the mean \pm S.E.M. $(n=6)$. * indicates a significant $(p$ $<0.05$ ) difference between overweight and underweight. A-3L: Large fish of 3-month old from A family, A3S: Small fish of 3 months from A family; B-3L: Large fish of 3-month old from B family, B-3S: Small fish of 3-month old from B family; A-5L: Large fish of 5- month old from A family, A-5S: Small fish of 5-month 
old from A family; B-5L: Large fish of 5-month old from B family, B-5S: Small fish of 5-month old from B family.
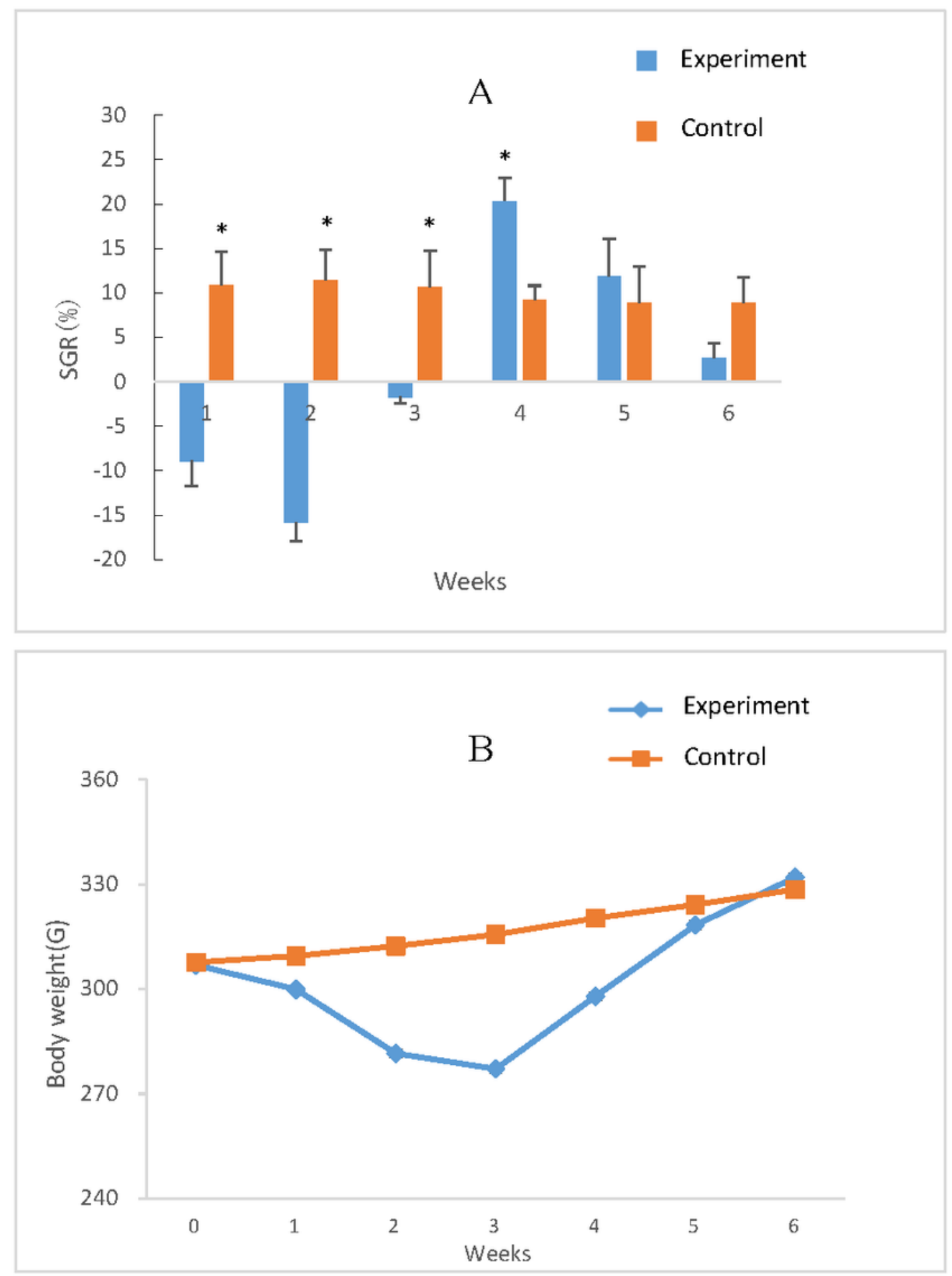

Figure 6

Growth curve and SGR of S.chuatsi during compensatory growth. (A) Growth curve of S.chuatsi during compensatory growth. Fish in experimental and control groups were weighted at six time points and the weights were subjected to curve drawn. In each time point, 6 S.chuatsi were random selected and 
weighted. Data are given as mean \pm standard deviation (S.D.). (B) SGR of S.chuatsi during compensatory growth. SGRs were calculated for control and experimental group during the six time intervals: The first three weeks (1,2,3 weeks) means $1,2,3$ weeks of fasting respectively, the last three weeks (4₫5『6 weeks) means 1,2,3 weeks of re-feeding. Asterisks represent significant differences between groups at each time intervals $(P<0.05)$ that calculated by $T$ - test.
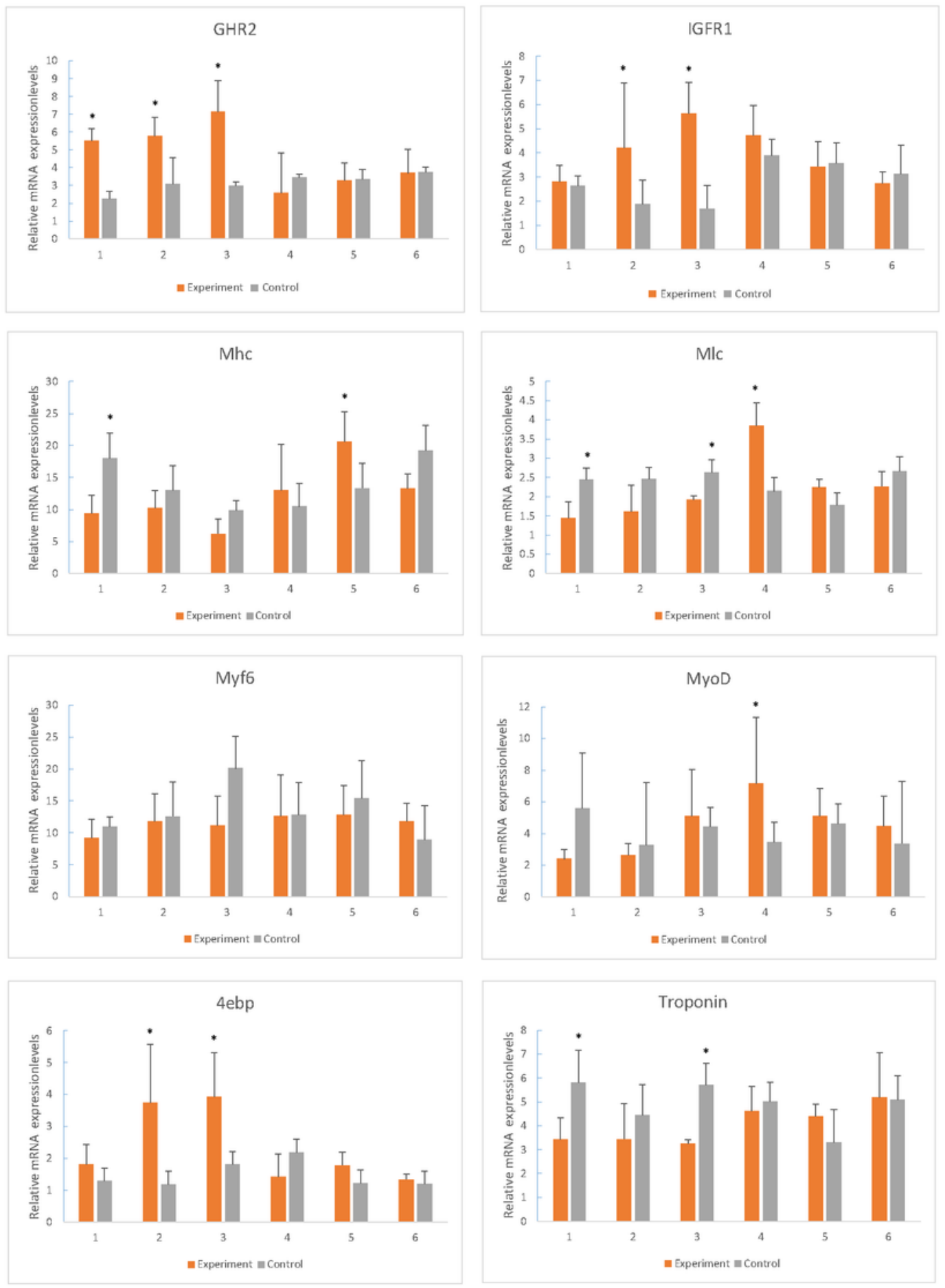

Figure 7 
Effects of fasting and re-feeding on muscle expression of growth-related genes in mandarin fish. After acclimated for a month, fish were divided into 2 groups ( $n=40$ /group). As for fed or re-fed group, fish were fed or fasted for 21 days, and at the end of experiment, fish were fed or re-fed for $6 \mathrm{~h}$ before sampling $\llbracket$ and in the fasted group, fish had been fasted before sampling. Times of sampling: times 1,2,3 means 1,2,3 weeks of fasting respectively, times 4,5,6 means 1,2,3 weeks after re-feeding. Each bar represents the mean \pm S.E.M. $(n=6)$. Significant differences at the $P<0.05$ level are indicated by * above the columns.

\section{Supplementary Files}

This is a list of supplementary files associated with this preprint. Click to download.

- NC3RsARRIVEGuidelinesChecklistfillable.pdf 